\title{
Experimental analysis on the combined effects of corrosion and fatigue in reinforced concrete beams
}

Análise experimental dos efeitos combinados de corrosão e fadiga em vigas de concreto armado

\section{Kássio J oe Stein Ângela Gaio Graeff}

I

nfrastructure elements, especially reinforced concrete bridges and viaducts, are exposed to a combination of degrading processes throughout their life cycle, such as corrosion and fatigue. The combined effects of both processes are known to be more harmful to the structure than the sum of both deterioration processes considered individually. Due to the limited amount of studies in this field, this research aims to evaluate, by experimental analysis, the combined effects of fatigue and corrosion on reinforced concrete beams. Eight beams measuring $7 \times 14 \times 130 \mathrm{~cm}$ were cast and divided in four groups of 2 beams each: one group for reference beams, one for corroded beams with a loss of mass of $10 \%$, one for beams subjected to 200,000 cycles and the last for corroded fatigued beams. The results show that the combined processes drastically reduce the load capacity of the beams by less than half compared to the reference beams. It was also observed that fatigue life decreased and the failure mode changed to fragile.

Keywords: Corrosion. Fatigue. Combined effects. Reinforced concrete beams. Experimental analysis.

\section{Resumo}

Elementos de infraestrutura, especialmente as pontes e viadutos de concreto armado, estão expostos a uma combinação de processos de degradação enquanto em serviço, como a corrosão de armaduras e fadiga. Os efeitos combinados de ambos os processos são conhecidos por serem mais prejudicais para a estrutura quando comparados à soma de ambos os processos de deterioração individualmente. Tendo em vista a limitação de estudos nessa área, essa pesquisa busca avaliar, por meio de análises experimentais, a combinação dos efeitos de fadiga e corrosão de armaduras em vigas de concreto armado. Para tanto, foram concretadas oito vigas com dimensões de $7 \times 14 \times 130 \mathrm{~cm}$, que posteriormente foram divididas em quatro grupos com duas vigas cada: um grupo para vigas de referência (sem degradação), um para vigas corroídas com perda de massa de armadura de $10 \%$, um para vigas submetidas a 200.000 ciclos de carregamento e o último para vigas corroídas e fatigadas. Os resultados mostram que a combinação de processos reduz drasticamente a capacidade de carga das vigas para menos da metade em comparação com as vigas referências. Também foi observado que a vida de fadiga diminuiu e o tipo de ruptura se alterou de dúctil para frágil.

Palavras-chave: Corrosão. Fadiga. Efeitos combinados. Vigas de concreto armado. Análise experimental.

Recebido em 03/10/18 


\section{Introduction}

Reinforced concrete bridges and viaducts are exposed to a combination of degrading processes, such as corrosion of the reinforcement caused by chloride or carbonation attack and fatigue caused by vehicle traffic. These structures are designed for a certain life cycle, based on the prediction of the volume of traffic at which the structure will be exposed to and the environmental conditions. However, both degrading processes are considered individually during the design process, which does not take into account the interaction between both processes. For instance, cyclic loads may cause microcracks in the concrete, which may lead to the easier ingress of aggressive agents (such as chlorides and carbon dioxide) through the concrete, thus causing corrosion. On the other hand, the corrosion process, depending on the degradation degree, may lead to bond loss and to cracks in the concrete cover, reducing the fatigue life of the concrete elements.

The interaction between fatigue and corrosion in reinforced concrete structures has been studied during the last twenty years; however, the area is still in need of deepening researches. Some studies focus on the fatigue behaviour of polymer reinforced corroded beams (SONG; YU, 2015; LOO; FOSTER; SMITH, 2012; AL-HAMMOUD; SOUDKI; TOPPER, 2011; SOUDKI et al., 2007). Other studies are based on experimental analysis of reinforced concrete elements subjected to corrosion and fatigue; usually these tests are based on the flexural performance of the elements (LIU; DIAO; ZHENG, 2015; WANG; LI; YI, 2015; GIORDANO; MANCINI; TONDOLO, 2011; YI et al., 2010; CHEN; ZHENG; WAND, 2009; OYADO; HASEGAWA; SATO, 2003). The influence of both degrading processes on the bond of reinforced concrete elements is also studied (FANG et al., 2006). Few studies focus on reliability and life prediction analysis of corroded fatigued elements (ZHANG et al., 2017; MA et al., 2014; MAES; WEI; DILGER, 2001).

This study focuses on an experimental analysis of the combined influence of corrosion and fatigue in reinforced concrete beams. Eight beams measuring $7 \times 14$ x $130 \mathrm{~cm}$ were cast; two beams were used as a reference with no degrading process; two beams were subjected to reinforcement corrosion at approximately $10 \%$ loss of mass; two beams were subjected to 200,000 fatigue cycles with a load capacity level of 0.5 and two beams were subjected to the combined effect of fatigue and corrosion. The results were obtained in terms of residual static flexural strength of the beams, aiming to compare the influence of each degrading process separately and combined.

\section{Literature review}

Despite being considered a new subject, the corrosion-fatigue effect has been studied in some research centres in recent years. These studies have shown to be promising, but in general, it has been found that there is a great difficulty in simulating in the laboratory both the effects of corrosion and fatigue occurring simultaneously, as in reality.

Oyado, Hasegawa and Sato (2003) explain that there are still no methods capable of evaluating corroded structures subjected to cyclic loading. Due to this factor, it is believed that the results obtained in the laboratory are less intense when compared with real situations. The need for more in-depth studies in the area arises, in order to improve the simulation of the corrosion-fatigue effect and to make the test closer to reality.

In 2009, a series of experiments was carried out with a specially designed equipment for the tests, capable of simulating corrosion and fatigue effects simultaneously. It was found that the test specimens submitted to 60 days of cure followed by 60 days of immersion in a corrosive solution, lost up to $17.8 \%$ of their flexural strength. On the other hand, the specimens submitted to 60 days of curing followed by 60 days of simulation of corrosion and fatigue effects lost up to $34.8 \%$ of their flexural strength. In general, the loss of flexural strength of test specimens subjected to fatigue and corrosion was almost twice the loss of flexural strength of those subjected to corrosion only (CHEN; ZHENG; WAND, 2009).

Further research carried out later observed that the increase in the degree of corrosion of the reinforcement decreased the fatigue strength of reinforced concrete beams, causing them to fracture fragile (YI et al., 2010; SUN; HUANG; REN, 2015). These studies found that beams with noncorroded reinforcements withstood more than $2,000,000$ cycles of fatigue, in other words, the fatigue test did not significantly influence the performance of the studied beams.

According to Sun, Huang and Ren (2015), the corroded beams showed brittle rupture, due to the rupture of one of the steel bars tensioned during the fatigue test. The non-corroded beams, submitted to 2 million cycles in the fatigue test, did not present inferior performance when submitted to the static bending test. 
In addition, it was observed that in beams with corroded reinforcement at $3.25 \%$ of mass loss, the number of cycles before rupture was reduced to 626,000 , so it is evident that even at low degrees of corrosion and non-perceptible cracking, the lifetime of the beam reduced drastically (YI et al., 2010).

In beams with $11.6 \%$ of mass loss, the number of cycles supported was only 89,000, which would indicate the great influence of the corrosion of the reinforcement in beams subjected to cyclic loads. These beams had fragile rupture and collapsed without any previous notice (YI et al., 2010).

Another study that reinforces the corrosion-fatigue effect was carried out by Coca et al. (2011). In this study they examined elements of bridges subjected to the effects of corrosion, fatigue and corrosionfatigue. It has been found that, when combined, the fatigue and corrosion effects can decrease the fatigue strength by about 20 to $30 \%$. The corrosionfatigue phenomenon was also studied by Wang, $\mathrm{Li}$ and Yi (2015). The research was based on the behavior of reinforced concrete beams and revealed the increase of the vertical displacement of corroded beams, when compared to beams that did not show corrosion, during the flexure test. Moreover, the reduction in the performance and stiffness of the corroded beams was observed. Similar to the study of Wang, Li and Yi (2015), the work performed by Zhang et al. (2017) evaluated corroded reinforced concrete beams subjected to fatigue test. It has been observed that the corrosion of the reinforcement rapidly reduces the performance and life stiffness when subjected to fatigue testing. This reduction occurs mainly because of the reinforcing bars failure at sites with corrosion concentration. The loss of bond between the reinforcement and the concrete did not cause significant reductions in the fatigue strength of the studied beams, but its effects in relation to the section curvature and deflection of the structure should be considered.

The loss of bond was also studied by Lin et al. (2017). The study found that, for both corroded and non-corroded test specimens, cyclic loading compared to static loading does not have any significant influence on bond or sliding of steel bars. However, the loss of bond is quite sensitive to the increased stress levels used in the fatigue tests. For example, when the stress level decreases from 0.9 to 0.7 in bars with $2 \%$ corrosion, there is a considerable increase in the number of cycles from 100 to about 5,000 .

In addition to experimental analyses, a probabilistic model for reinforced concrete structures, which considers the effect of corrosion and cyclic loading on the useful life of reinforcements, was proposed by Bastidas-Arteaga et al. (2008). This model considered different loading frequencies and different classes of aggressiveness. The results concluded that the level of corrosion is more influential than the loading frequency. Through a mathematical model, the authors have proven that the shift from low aggressive environment to high aggressive environment is up to fourteen times more influential than variations in loadings.

\section{Research method}

\section{Materials}

Eight beams measuring $7 \times 14$ x $130 \mathrm{~cm}$ with a 25 MPa characteristic strength concrete were used for the experiments. The mix proportion of the concrete was $291 \mathrm{~kg} / \mathrm{m}^{3}$ of High Early Strength cement, 844 $\mathrm{kg} / \mathrm{m}^{3}$ river dragged sand and $1048 \mathrm{~kg} / \mathrm{m}^{3}$ basalt coarse aggregate. The gradation curves of the aggregates are presented in Figure 1. Most of the sand was classified in the great zone and the coarse aggregate presented granulometric scale of 9.5/25, according to NBR 7211 (ASSOCIAÇÃO..., 2009). The characterization of the cement is shown in Table 1 . The water to cement relation was 0.65 . This proportion was based on previous experiments developed by Graeff (2007), whose studies used the same method to simulate corrosion and control the corrosion rate. The casting was divided in two groups due to limitation of the mixer capacity. The compressive strength of each group is shown in Table 2. The specimens were cylinders measuring $100 \mathrm{~mm}$ in diameter and $200 \mathrm{~mm}$ in height. The average compressive strength after 28 days curing, measured according to NBR 5738 (ASSOCIAÇÃO..., 2015) was $32.04 \mathrm{MPa}$. The slump test results of Group 1 and 2 were similar, 19 and $18 \mathrm{~cm}$, respectively. The reinforcement steel used is shown in Figure 2. The hanger bars and stirrups were made of CA-60 and their diameter was $5 \mathrm{~mm}$. The anchor bars had $8 \mathrm{~mm}$ diameter and were made of CA- 50 . The stirrups spacing was $5 \mathrm{~cm}$. The bars and stirrups were attached to each other with annealed wire 18 .

For the beams subjected to corrosion, prior to casting of specimens, the reinforcement was prepared with a copper wire to allow the acceleration of the corrosive process, as described next in the methodology section. The copper wire was placed above the longitudinal steel bar, attached to the shear stirrups, in such way that the wire was close but not in contact with the longitudinal bar, as shown in Figure 3. This procedure was carried out to reduce the probability of pitting. 
Figure 1 - Gradation curves of aggregates

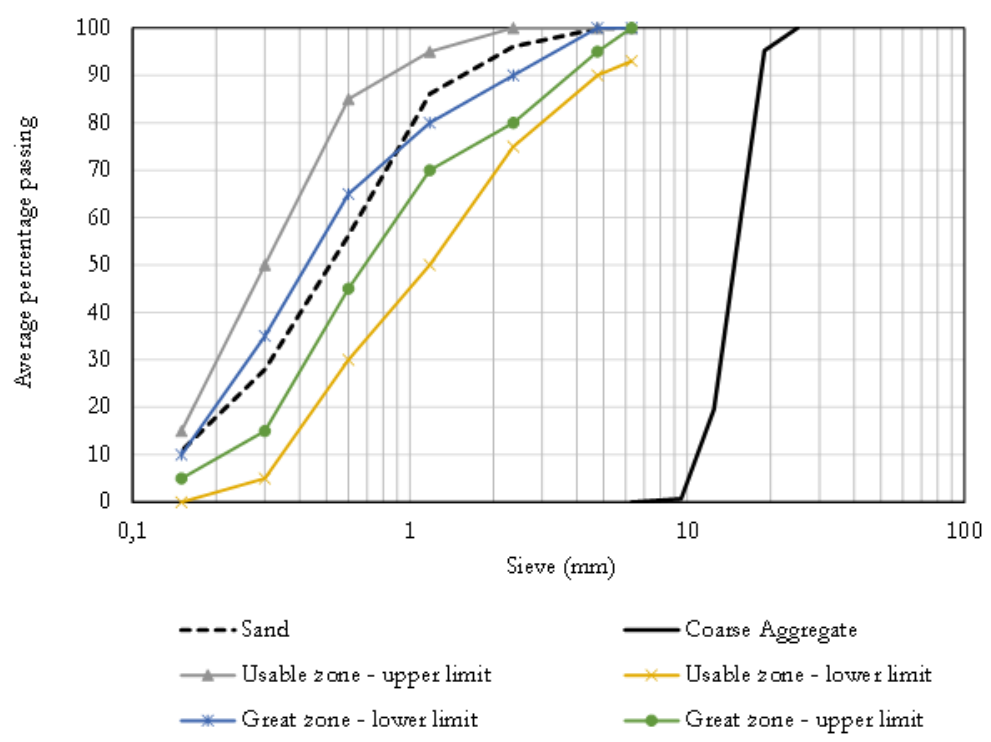

Table 1 - Cement characterization

\begin{tabular}{l|c|c}
\hline \multicolumn{1}{c|}{ Property } & & \\
\hline Specific surface - Blaine & 0.4401 & $\mathrm{~m}^{2} / \mathrm{g}$ \\
Initial set time (ABNT, 2003) & 140 & $\mathrm{~min}$ \\
Final set time (ABNT, 2003) & 187 & $\mathrm{~min}$ \\
Specific gravity (ABNT, 2001) & 3.11 & $\mathrm{~g} / \mathrm{cm}^{3}$ \\
Average diameter & 11.06 & $\mu \mathrm{m}$ \\
Loss on ignition & 2.56 & $\%$ \\
$\mathrm{SiO}_{2}$ & 17.83 & $\%$ \\
\hline
\end{tabular}

Table 2 - Compressive Strength

\begin{tabular}{c|c|c|c|c|c|c|c|c|c|c|c}
\hline & \multicolumn{4}{|c|}{ Group 1 } & \multicolumn{2}{c|}{ Group 2 } & & & & \\
\cline { 1 - 7 } $\begin{array}{c}\text { Specimen } \\
\text { number }\end{array}$ & $\mathbf{1}$ & $\mathbf{2}$ & $\mathbf{3}$ & $\mathbf{4}$ & $\mathbf{5}$ & $\mathbf{6}$ & $\mathbf{7}$ & $\mathbf{8}$ & $\mathbf{9}$ & $\mathbf{1 0}$ & Average \\
\hline $\begin{array}{c}\text { Compressive } \\
\text { strength [MPa] }\end{array}$ & 33,61 & 36,99 & 34,76 & 34,90 & 32,95 & 29,99 & 28,88 & 27,47 & $\mathbf{2 8 , 6 2}$ & 32,27 & 32,04 \\
\hline
\end{tabular}

Figure 2 -Reinforcement steel configuration

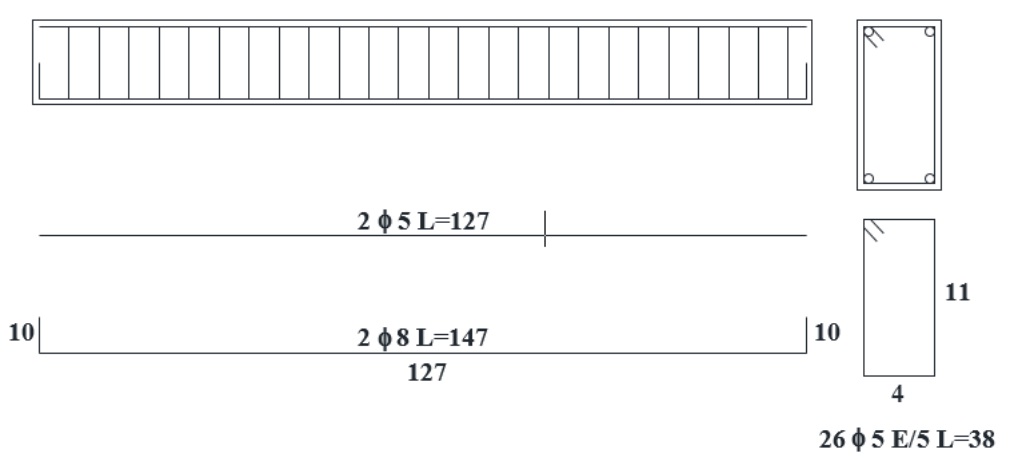


Figure 3 - Detail of the installation of copper wire

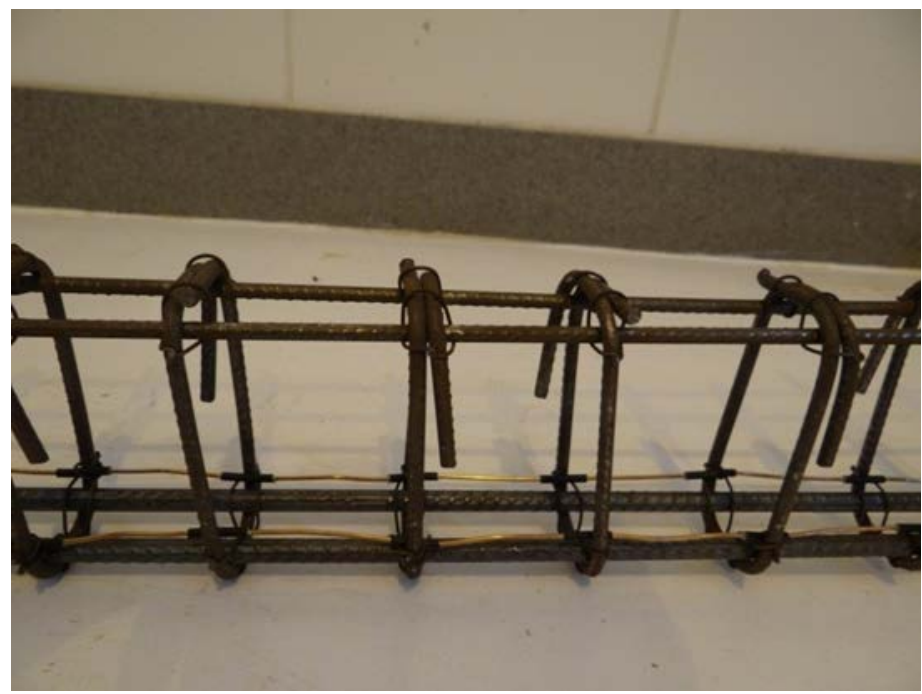

The beams were cast following the procedures of NBR 5738 (ASSOCIAÇÃO..., 2015). They were placed in ambient temperature and humidity for 24 hours. After this period, they were demoulded and placed in a controlled temperature room $\left(23 \pm 2{ }^{\circ} \mathrm{C}\right)$ for 28 days. During this curing period the beams were covered with cloths and wet daily to allow the hydration of the cement products.

\section{Methodology}

After the curing period, the eight beams were divided in four groups of two beams each. Two beams were used as reference (RE) and no degrading processes were applied to them. Two beams were subjected to reinforcement corrosion (CO), two beams were subjected to fatigue loads (FA) and, finally, two beams were subjected to the combined effects of corrosion and fatigue (CF).

For the beams subjected to corrosion (CO) and corrosion combined to fatigue (CF), the intended corrosion degree was $10 \%$ by loss of mass of steel, which is considered critical in terms of structural behaviour (GRAEFF, 2007). The corrosion process was simulated electrochemically by chloride ingress. It's important to notice that the concrete cover represents a physical barrier against the ingress of any aggressive agents and plays an essential role when the problem is corrosion. According to NBR 6118 (ASSOCIAÇÃO..., 2014), the concrete cover of the reinforced concrete structures exposed to high aggressive environment should be 35 to $40 \mathrm{~mm}$, depending on the structural element. However, the beams in this research were cast with concrete cover of $15 \mathrm{~mm}$ due to their geometric limitations. The schematic procedure used to accelerate corrosion is shown in Figure 4. In this procedure, the beams are placed in a separate plastic pool with a $35 \mathrm{~g} / \mathrm{l}$ chloride solution up to concrete cover of the beams. Plastic supports with $10 \mathrm{~mm}$ are placed below the beams to allow the solution to be in contact with the bottom part of beams. A power supply was used to allow the constant flow of $500 \mu \mathrm{A} / \mathrm{cm}^{2}$. This flow was chosen based on studies developed by Graeff (2007) and El Maaddawy and Souki (2003). Current flow rates above $500 \mu \mathrm{A} / \mathrm{cm}^{2}$ tend to create a cracking degree that does not represent what actually happens in real structures; on the other hand, low current flow rates would compromise the research schedule. The area that is considered is the one in contact with concrete and not the section area. A two-electrode system is used to apply the current. The counter electrode is immersed in the solution whilst the working electrode is connected to the copper wire installed prior to the casting of samples.

The beams were subjected to the corrosive process to reach $10 \%$ of loss of mass of longitudinal bars. The period for corrosion acceleration (tc, in seconds) was calculated following studies developed by Graeff (2007), which were based on Faraday's law (EL MAADDAWY; SOUDKI, 2003; FANG et al., 2004; HELENE, 1993), and is presented in Equation 1.

$t c=\left[\left(\frac{\Delta \mathrm{m} \times \mathrm{z} \times \mathrm{F}}{\mathrm{M} \times \mathrm{I}}\right) \times 1.1778\right]+357825 \quad$ Eq. 1

Where:

$\Delta \mathrm{m}=$ the mass of steel consumed (g);

$\mathrm{M}=$ atomic weight of the metal ( $56 \mathrm{~g}$ for $\mathrm{Fe}$ );

$\mathrm{I}=\operatorname{current}(\mathrm{A})$;

$\mathrm{z}=$ ionic charge (2);

$\mathrm{F}=$ Faraday's constant $(96,500 \mathrm{~A} / \mathrm{s})$; and

$\mathrm{tc}=$ time of corrosion (s). 
After applying the equation, the corrosion period was established as 30 days.

For the beams subjected to fatigue (FA) and corrosion combined to fatigue (CF), the predicted number of cycles was 200,000. This number was based on studies by Meneghetti (2007) who tested the flexural response of non-corroded beams of similar geometry, reinforcement, and concrete. The stress level variation used in Meneghetti's studies was $8 \%$ to $61 \%$. The beams withstand from 194,000 to 383,000 cycles.

In order not to have premature failure of the beams a conservative view was adopted. The upper loading limit was $50 \%$ of the ultimate load capacity, based on the static flexural test carried out on RE beams. The lower loading limit was equal to $5 \%$ of the same ultimate load capacity. The cycles were applied at the frequency of $5 \mathrm{~Hz}$.

The flexural fatigue loads were applied following a third point flexural test configuration, as shown in Figure 5. The same configuration was used to perform the static flexural tests to determine the load capacity of RE mixes.
The CF beams were first subjected to corrosion and later subjected to fatigue. It is importante to note that this order may influence the results, since the beams would be already corroded (with severe structural loss) when subjected to fatigue. In reality, both degrading processes would occur at the same time. However, the experimental logistics to accelerate both processes at the same time is extremely difficult, if not impossible considering the available infrastructure for the research.

After exposing the CO, FA and CF beams to degrading processes, they were subjected to static flexural test, to measure their residual load capacity, and the results were compared among them.

\section{Results and discussions}

RE beams were tested to determine the load capacity in the static flexural testing apparatus. The load capacity of both beams was $40 \mathrm{kN}$ and $39.4 \mathrm{kN}$, leading to an average of $39.7 \mathrm{kN}$. This value was used to calculate the fatigue load, based on $50 \%$ of the static test, leading to a value of $19.9 \mathrm{kN}$.

Figure 4 -Schematic procedure to accelerate corrosion

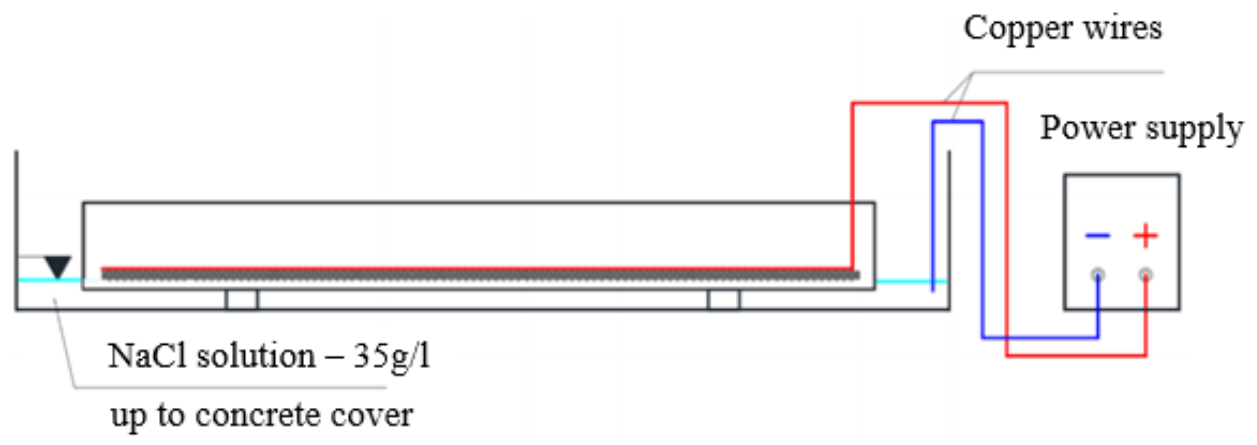

Figure 5 - Load configuration for static and fatigue flexural tests

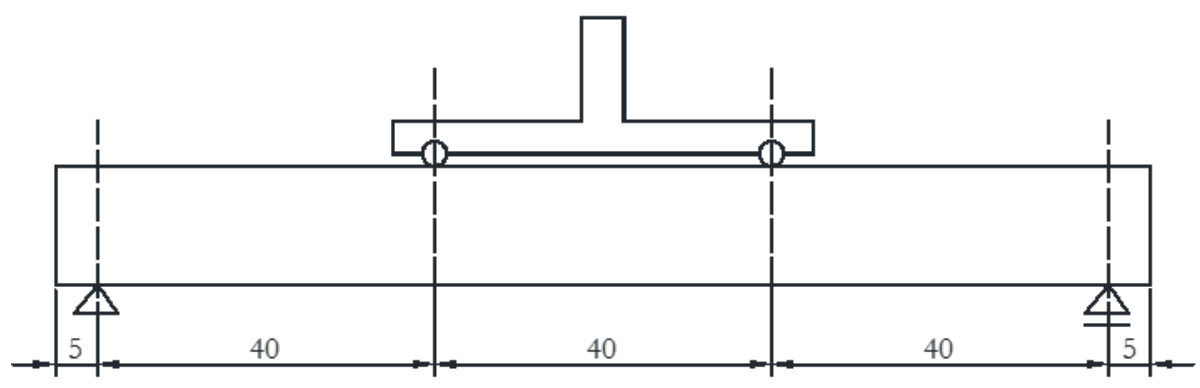

units in $\mathrm{cm}$ 
$\mathrm{CO}$ beams were also tested in the static flexural testing apparatus and the results were $37.6 \mathrm{kN}$ (CO 9\%) and $34.5 \mathrm{kN}$ (CO 14\%). After the test, the concrete cover of the beams was removed to allow the access to the longitudinal bars. Two fractions of $500 \mathrm{~mm}$ length of the bars located in the centre of the specimens were removed and cleaned according to G1 (AMERICAN..., 2011) to calculate the actual loss of mass of the bars. The loss of mass measured was $9 \%$ and $14 \%$, which explains the codes "CO $9 \%$ " and "CO 14\%" to differentiate the beams. These results indicate that, even though the current rate was constant, there is variability on the prediction of the loss of mass, probably because it is not possible to isolate the stirrups during the corrosion process, which means that the actual current rate applied may be lower. This fact may explain the lower value of $9 \%$. The fact that one of the bars had a loss of mass of $14 \%$ (higher than the predicted $10 \%$ ) is probably because this beam was subjected, for a period lower than $24 \mathrm{~h}$, to a much higher current rate, caused by malfunction of the power supply.

The failure of beam CO 9\% occurred because of the concrete crushing in the compressed area, as shown in Figure 6. Beam CO $14 \%$ had its concrete debonded and its failure was due to a main crack in the pure flexural zone, according to Figure 7. Debonding is justified by the higher degree of corrosion and the amount of corrosion products. The comparison between the CO beams showed that the CO 14\% had higher vertical displacement than the CO 9\% for the same load, as expected. FA beams were subjected to cyclic loads when they were at the age of 60 days, just after finalising the corrosion process on $\mathrm{CO}$ beams. After applying the 200,000 cycles, the specimens were visually observed and no signs of microcracks were found at the surface of the concrete. This fact was expected, since the number of cycles is relatively low in comparison to the number of cycles that infrastructure elements are subjected during their life cycle. However, this low number of cycles was chosen because it was not possible to predict the number of cycles that corroded beams would resist. Hence, to avoid losing specimens, the conservative number of 200,000 cycles was initially the target for all beams subjected to fatigue.

CF beams were first subjected to corrosion and later to cyclic loads. However, at the moment the fatigue loads were applied it was possible to observe at a point close to 170.000 cycles that the vertical displacements and the number of cracks in the beams were increasing considerably. To avoid losing the specimens, the cyclic loads were interrupted and the specimens saved for final static flexural test.

The graph of the load versus vertical displacement of the eight beams analysed in this research is presented in Figure 8. It is important to note that the displacements were manually recorded in intervals of $5 \mathrm{kN}$. The measurement system used was an analogic dial indicator Mitutoyo 50/0.01 mm 3058E.

It is important to mention that the last recorded point shown in the graph is not the load capacity of the beams, but the point at which it was possible to obtain the displacement. After this measurement, the beams were loaded up to failure and the measurement system removed to avoid damaging it. Load was applied in an in-between $5 \mathrm{kN}$ load interval. Table 3 shows the load capacity of the eight beams.

\section{Figure 6 - Crushing of the compressed area of beam CO 9\%}

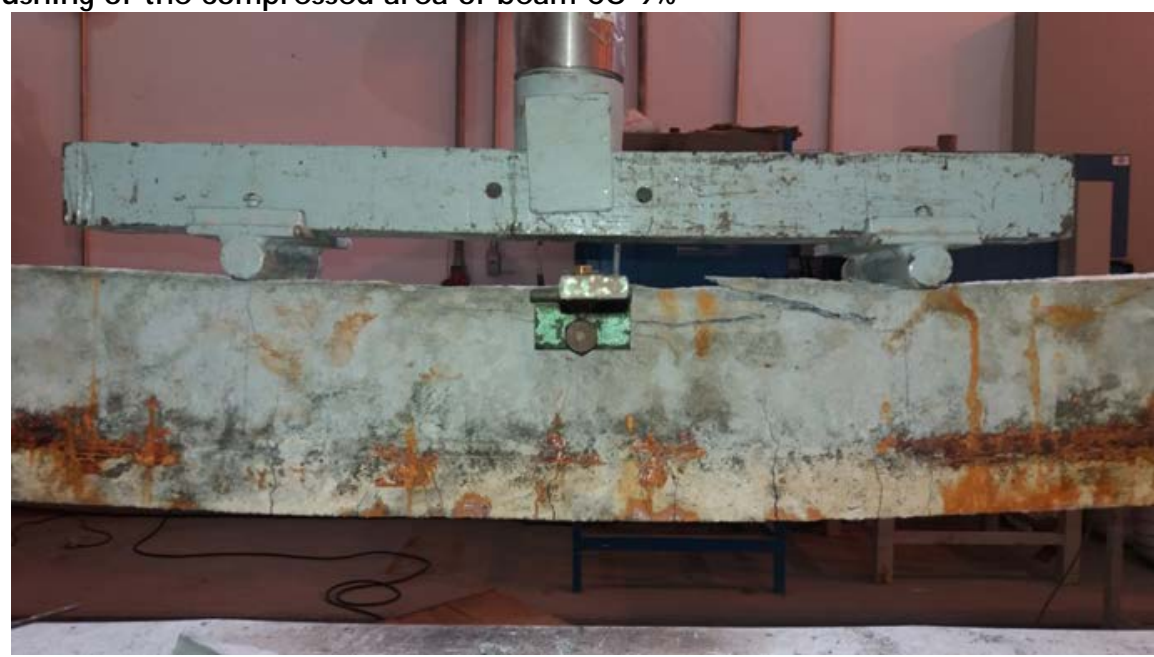


higher than all other beams for loads above $10 \mathrm{kN}$. This behaviour was already expected considering the increasing in the displacements and number of cracks observed during the fatigue cycles, and it is probably caused by the loss of bond between steel and concrete, the reduction on the cross-sectional area of steel bars and the presence of cracks originated from the corrosion process. Figures 9, 10 and 11 show the vertical displacements at loads of 10,15 , and $20 \mathrm{kN}$.

The cyclic loads, when applied to the already deteriorated CO beams, were much more harmful than the ones applied to RE beams. This can be confirmed by the higher vertical displacements showed by the CF beams and the reduction of their load capacity in comparison to the other beams. The cracking behavior indicates the change of the failure mode of the beams. The RE, FA and CO 9\% beams had ductile failure, after the opening of several cracks in the maximum bending region, followed by the crushing of concrete in the compressive zone. However CO 14\% and CF beams had brittle failure mode, characterized by showing a low number of cracks, and a sudden collapse. The crack mapping of the beams is shown in Figures 12 and 13. Figure 14 shows a schematic representation of the previous figures to facilitate the visualization of the mapping.

\section{Conclusions}

The following conclusions can be drawn from the development of this research:

Damages caused in beams subjected to combined effects of corrosion and fatigue are much higher than if the effects are considered individually. This can be noted by the reduction of the load capacity and by the increase in the vertical displacements of the beams.

The reduction on the load capacity of corroded fatigued beams was more than half of the capacity of reference beams.

Even though there was an increase in the vertical displacements of beams subjected to corrosion and fatigue, a premature failure was observed following the tests.

\section{Figure 9 - Vertical displacement $(\mathrm{mm})$ - $10 \mathrm{kN}$}

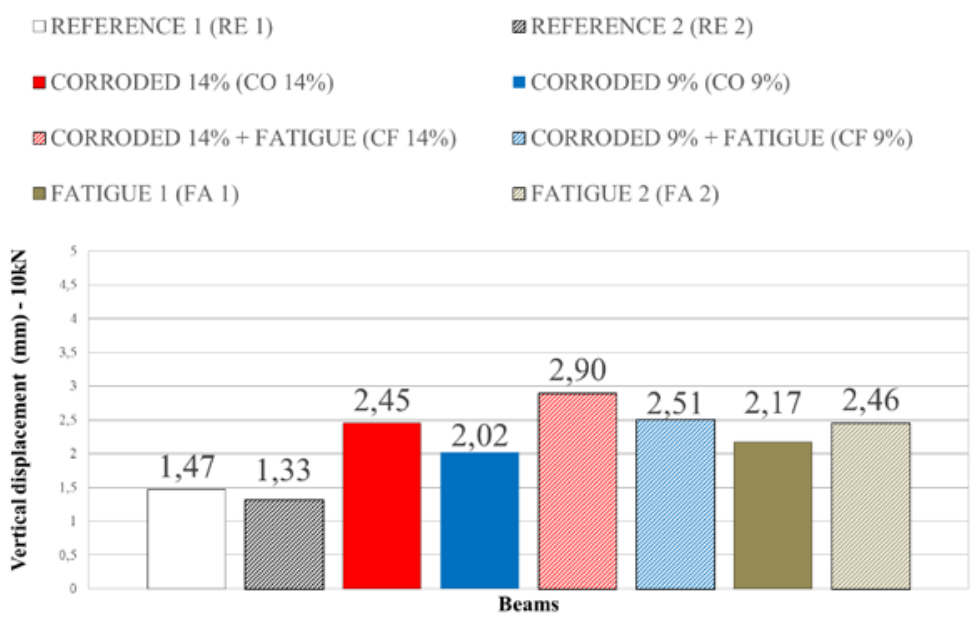

Figure 10 - Vertical displacement (mm) - 15 kN
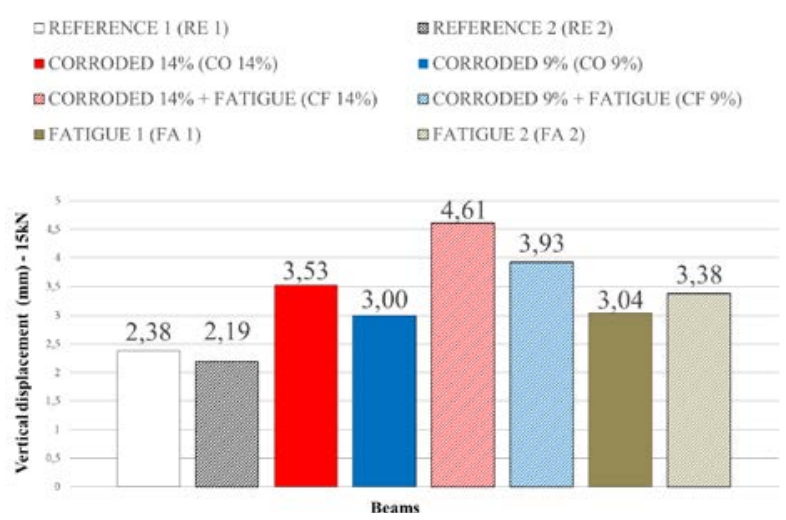
Figure 11 - Vertical displacement $(\mathrm{mm})$ - 20 kN
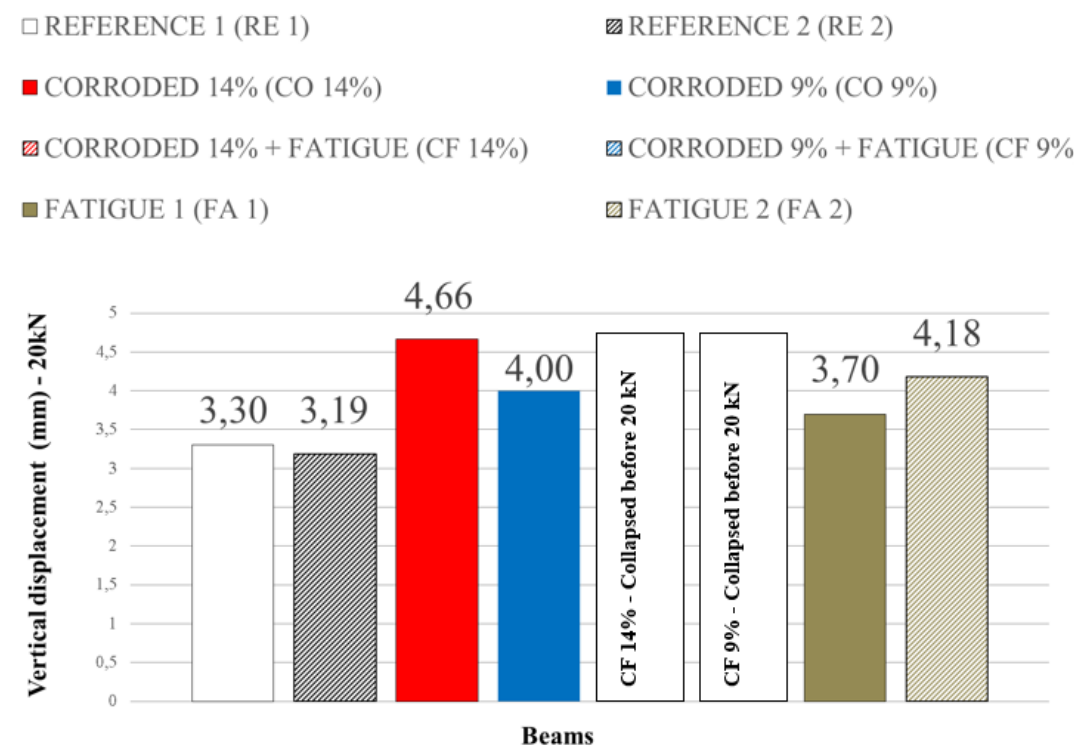

Figure 12 - Crack mapping of the $\mathrm{CO}$ and RE beams

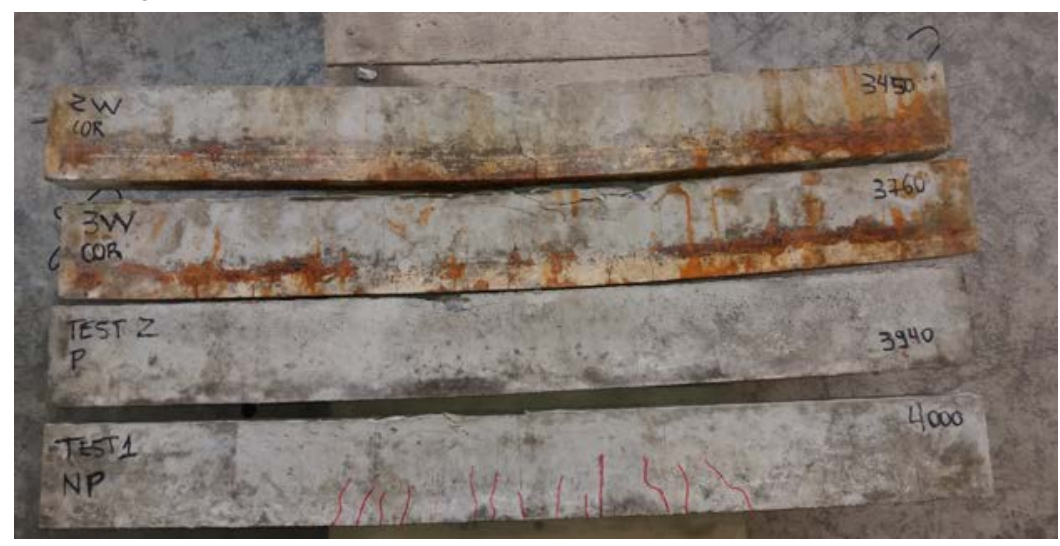

Figure 13 - Crack mapping of the CF and FA beams

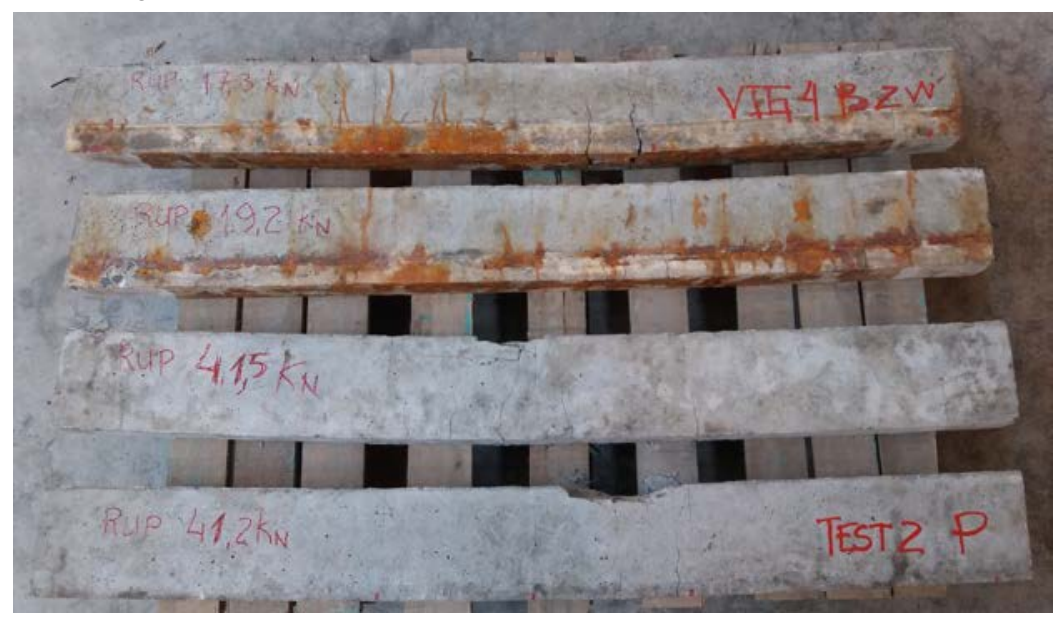


Figure 14 - Crack mapping of the beams

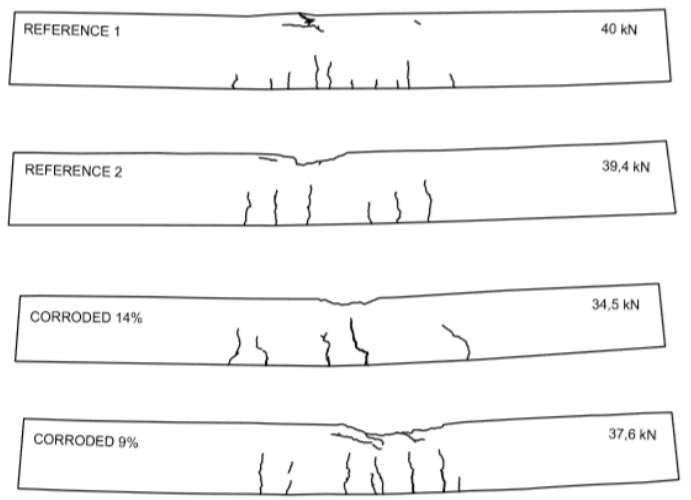

The structural implications of the combined effects of corrosion and fatigue shown in this paper are probably caused by the loss of bond between concrete and steel, the reduction of the crosssectional area, the formation of cracks and the detaching of the concrete cover, all caused by corrosion and magnified by fatigue.

Fatigue cycles alone did not influence in the load capacity. None of the fatigued beams presented visual cracks after the cyclic loads, however the vertical displacement in the static flexural test was in general higher than the reference beams.

Corroded beams showed a higher vertical displacement in comparison to reference beams, probably due to reduction of the steel bar section and the loss of bond between the bars and concrete. The corrosion process reduced the load capacity by $10 \%$ in comparison with the load capacity of the reference beams.

The fact that corrosion was simulated prior to fatigue is probably to affect the results. In reality, fatigue and corrosion occur at the same time; however, it is very difficult, if not impossible, to simulate both degrading processes at the same time.

The results are based on only two degrees of corrosion and specific parameters for fatigue test. Hence, the conclusions drawn from this work cannot be extended to any other variable that is not mentioned in this study.

More studies should be done in order to acquire more information about the behaviour of the beams with different corrosion degrees. Concretes with other characteristic strengths should also be considered.
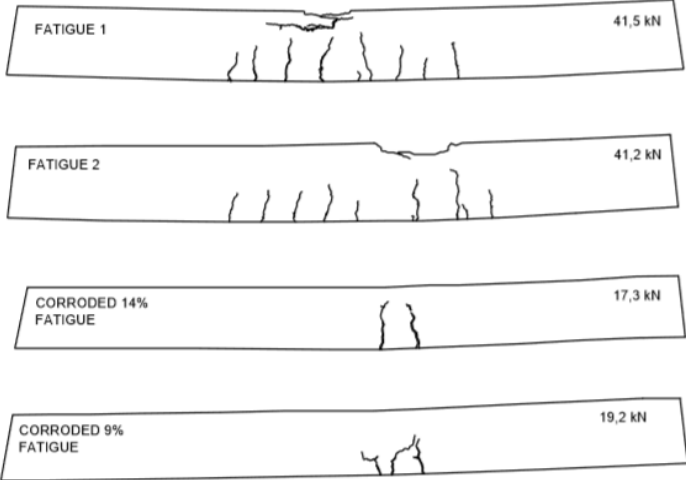

\section{References}

AL-HAMMOUD, R.; SOUDKI, K.; TOPPER, T. H. Fatigue Flexural Behavior of Corroded Reinforced Concrete Beams Repaired With CFRP Sheets. Journal of Composites for Construction, v. 15, p.45-51, 2011.

\section{AMERICAN SOCIETY FOR TESTING AND}

MATERIALS. G1: standard practice for preparing, cleaning and evaluating corrosion test specimens. Philadelphia, 2011.

\section{ASSOCIAÇÃO BRASILEIRA DE NORMAS} TÉCNICAS. NBR 5738: concreto: procedimento para moldagem e cura de corpos de prova. Rio de Janeiro, 2015.

ASSOCIAÇÃO BRASILEIRA DE NORMAS

TÉCNICAS. NBR 6118: projeto de estruturas de concreto: procedimento. Rio de Janeiro, 2014.

ASSOCIAÇÃO BRASILEIRA DE NORMAS TÉCNICAS. NBR 7211: agregado para concreto: especificação. Rio de Janeiro, 2009.

ASSOCIAÇÃO BRASILEIRA DE NORMAS TÉCNICAS. NBR NM 23: cimento portland e outros materiais em pó: determinação da massa específica. Rio de Janeiro, 2001.

ASSOCIAÇÃO BRASILEIRA DE NORMAS TÉCNICAS. NBR NM 65: cimento Portland: determinação do tempo de pega. Rio de Janeiro, 2003.

BASTIDAS-ARTEAGA, E. et al. Coupled Reliability Model of Biodeterioration, Chloride Ingress and Cracking for Reinforced Concrete Structures. Structural Safety, v. 30, n. 2, p. 110129, 2008. 
CHEN, S.-F.; ZHENG, M.-L.; WAND, B.-G. Study of High-Performance Concrete Subjected to Coupled Action from Sodium Sulfate Solution and Alternating Stresses. Journal of Materials in Civil Engineering, v. 21, p. 148-153, 2009.

COCA, F. O. et al. Corrosion Fatigue of Road Bridges: a review. International Journal of Electrochemical Science, v. 6, p. 3438-3451, 2011.

EL MAADDAWY, T. A.; SOUDKI, K. A. Effectiveness of Impressed Current Technique to Simulate Corrosion on Steel Reinforcement in Concrete. Journal of Materials in Civil Engineering, v. 15, n. 1, 2003.

FANG, C. et al. Corrosion Influence on Bond in Reinforced Concrete. Cement and Concrete Research, v. 34, n. 11, p. 2159-2167, 2004.

FANG, C. et al. Effect of Corrosion on Bond in Reinforced Concrete Under Cyclic Loading. Cement and Concrete Research, v. 36, p. 548555, 2006.

GIORDANO, L.; MANCINI, G.; TONDOLO, F. Reinforced Concrete Members Subjected to Cyclic Tension and Corrosion. Journal of Advance Concrete Technology, v. 9, n. 3, p. 277-285, 2011.

GRAEFF A. G. Avaliação Experimental e Modelagem dos Efeitos Estruturais da Propagação da Corrosão em Elementos de Concreto Armado. Porto Alegre, 2007. Dissertação (Mestrado em Engenharia Civil) Programa de Pós-Graduação em Engenharia Civil, Universidade Federal do Rio Grande do Sul, Porto Alegre, 2007.

HELENE P. R. L. Contribuição ao Estudo da Corrosão em Estruturas de Concreto Armado. São Paulo, 1993. Tese (Livre docência) Departamento de Engenharia de Construção Civil, Universidade de São Paulo, São Paulo, 1993.

LIN, H. et al. The Bond Behavior Between Concrete and Corroded Steel Bar Under Repeated Loading. Engineering Structures, v. 140, p. 390405, 2017.

LIU, Z.; DIAO, B.; ZHENG, X. Effects of Seawater Corrosion and Freeze-Thaw Cycles on Mechanical Properties of Fatigue Damaged Reinforced Concrete beams. Advances in Materials Science and Engineering, art. 536487, 2015.
LOO, K. Y. M.; FOSTER, S. J.; SMITH, S. T. Fatigue Behavior of Carbon Fiber-Reinforced Polymer-Repaired Corroded Reinforced Concrete Beams. ACI Structural Journal, v. 109, n. 6, p.795-803, 2012.

MA, Y. et al. Fatigue Life Prediction for Aging RC Beams Considering Corrosive Environments. Engineering Structures, v. 79, p. 211-221, 2014.

MAES, M. A.; WEI, X.; DILGER, W. H. Fatigue Reliability of Deteriorating Prestressed Concrete Bridges Due to Stress Corrosion Cracking.

Canadian Journal of Civil Engineering, v. 28, p. 673-683, 2001.

MENEGHETTI, L. C. Análise do

Comportamento à Fadiga de Vigas de Concreto Armado Reforçadas com PRF de Vidro, Carbono e Aramida. Porto Alegre, 2007. 275 f. Tese (Doutorado em Engenharia Civil) Universidade Federal do Rio Grande do Sul, Porto Alegre, 2007.

OYADO, M.; HASEGAWA, M.; SATO, T. Characteristics of Fatigue and Evaluation of RC Beam Damaged by Accelerated Corrosion. Quartely Report of Railway Technical Research Institute, v. 44, n. 2, p. 72-77, 2003.

SONG, L.; YU, Z. Fatigue Performance of Corroded Reinforced Concrete Beams Strengthened With CFRP Sheets. Construction and Building Materials, v. 90, p. 99-109, 2015.

SOUDKI, K. A. et al. Fatigue Strength of FibreReinforced-Polymer-Repaired Beams Subjected to Mild Corrosion. Canadian Journal of Civil Engineering, v. 34, p. 414-421, 2007.

SUN, J.; HUANG, Q.; REN, Y. Performance Deterioration of Corroded RC Beams and Reinforcing Bars Under Repeated Loading. Construction and Building Materials, v. 96, p. 404-415, 2015.

WANG, L.; LI, C.; YI, J. An Experimental Study on Behavior of Corrosion RC Beams with Different Concrete Strength. Journal of Coastal Research, v. 73, p. 259-264, 2015.

YI, W.-J. et al. Fatigue Behavior of Reinforced Concrete Beams With Corroded Steel Reinforcement. ACI Structural Journal, v. 107, n. 5, p. 526-536, 2010.

ZHANG, W. et al. Assessment of Fatigue Life for Corroded Reinforced Concrete Beams Under Uniaxial Bending. Journal of Structural Engineering, v. 143, n. 7, 2017. 


\section{Acknowledgements}

The authors are grateful for the support of the Laboratory of Testings and Structural Models (LEME) and the Laboratory of Physics Metallurgy
(LAMEF) of the Federal University of Rio Grande do Sul for allowing access to their infrastructure and equipments to carry out the tests. The authors also thank ArcelorMittal for providing the reinforcement bars and stirrups used in the concrete beams.

\section{Kássio J oe Stein}

Departamento de Engenharia Civil | Universidade Federal do Rio Grande do Sul | Av. Osvaldo Aranha, 99, 30 andar | Porto Alegre - RS Brasil | CEP 90035-190 | Tel.: (51) 3308-3450 | E-mail: kassio86@hotmail.com

\section{Ângela Gaio Graeff}

Departamento de Engenharia Civil | Universidade Federal do Rio Grande do Sul | E-mail: angel.graeff@gmail.com

Revista Ambiente Construído

Associação Nacional de Tecnologia do Ambiente Construído

Av. Osvaldo Aranha, 99 - 3o andar, Centro

Porto Alegre - RS - Brasil

$$
\text { CEP } 90035-190
$$

Telefone: +55 (51) 3308-4084

Fax: +55 (51) 3308-4054

www. seer. ufrgs. br/ ambienteconstruido

E-mail: ambienteconstruido@ufrgs.br 